\title{
From the Stone the Builders Rejected: Towards a New Civil Rights Historiography
}

\section{Jeanne Theoharis}

Brooklyn College_-City University of New York

Kenneth Andrews, Freedom Is a Constant Struggle: The Mississippi Civil Rights Movement and its Legacy (Chicago: University of Chicago Press, 2004).

Martha Biondi, To Stand and Fight: The Struggle for Civil Rights in Postwar New York (Cambridge, Mass.: Harvard University Press, 2003).

Waldo Martin, No Coward Soldiers: Black Cultural Politics and Postwar America (Cambridge, Mass.: Harvard University Press, 2005).

Nikhil Pal Singh, Black Is a Country: Race and the Unfinished Struggle for Democracy (Cambridge, Mass.: Harvard University Press, 2005).

Notions of the American nation are bound inextricably to the promise of liberal democracy, and, in contemporary political thought, the Civil Rights movement stands as one of its shining hours. Watching the week-long spectacle attending Rosa Parks' funeral last year or the rolling celebrations which begin with the King holiday and continue through Black History month make clear how crucial the movement is for American self-identity. As the popular story goes, a landmark 1954 Supreme Court decision in Brown v. Board of Education and a courageous act by Rosa Parks touched off a grassroots movement that reshaped the South and, consequently, the nation. Led by the Reverend Martin Luther King, Jr. and the ministers of the Southern Christian Leadership Conference and the daring youth of the Student Nonviolent Coordinating Committee and Freedom Summer, courageous black folks and their white allies across the South faced brutal violence and economic repression in their quest for justice. With the support of two presidents, they succeeded in getting the passage of two essential laws-the 1964 Civil Rights Act and the 1965 Voting Rights Act-while undoing Jim Crow segregation and the legacies of plantation slavery in the South. This nonviolent revolution showed the resiliency and redemptive power of American democracy; it succeeded in correcting a crucial flaw in American democracy without overthrowing the government or engaging in a bloody revolution. ${ }^{1}$ The story of the civil rights movement thus testifies to the American value of dissent and self-improvement.

Writing against these notions of American redemption, the four books reviewed here are part of a dramatic shift in Civil Rights historiography and, in turn, how we view the American project. They join a host of new scholarship that, over the past decade, has returned to every detail in that popular story and exca- 
vated beneath it; that has an ushered a new set of characters and events to the stage and then begun to rewrite the entire play. ${ }^{2}$ This sea change in movement history reminds us that the movement became American only after the fact, long after its victories were common sense and many of its leaders dead. While the March on Washington is now held up as glorious day in American history, it was feared and reviled by most Americans at the time (two-thirds of those surveyed in a Gallup poll days before the March called it 'un-American'). While Martin Luther King Jr. is consistently listed today as a hero by elementary schoolers across the country, from 1955-1968, he was surveilled by the federal government, called unAmerican by a wide swath of the American public, and blasted for his willingness to extend the call for racial justice and nonviolence to America's war in Vietnam and to the deep economic divisions at home.

Taken together, these four books help reshape the borders of the movement, the regionalization and periodization of the struggle, and the variety of tools employed in the fight for social change. These studies return five crucial decades (the 1930s-1970s) to movement history, nationalize the movement (by showing some of the battlefields outside of the South), and foreground the role of culture and local organizing in the black nationalist project of self determination. They look at the international dimensions of the struggle both in terms of the constraints of the Cold War on American radicalism but also of a Bandung world where African Americans had a crucial role to play in imagining and creating an anti-colonial order. In turn, they reveal the good movement (1954-1965) only succeeded through its dangerous predecessors (pre- and postwar left activism) and its militant stepchild (Black Power). They show less the perfectibility of the American nation than the ways that a variety of thinkers and actors made visible the whiteness at the heart of American nationalism and in doing so changed the nation (even as some sought to leave it).

Waldo Martin's No Coward Soldiers: Black Cultural Politics and Postwar America contains three essays adapted from talks he gave at Harvard University as part of the Nathan Huggins Lectures. Martin's overriding theme in these essays is to show the work of culture-from music to sports to photography — in the black liberation struggles of the 1950s-1970s. Martin persuasively establishes the role of cultural production in mapping out both the vision and the sustenance for the struggle. The challenge of the movement stemmed not just from challenging an entrenched political, economic and social system of racial inequity but, as historian Robin Kelley has termed it, in creating "freedom dreams," the ways people imagined and created the landscape for a new just order. ${ }^{3}$ And Martin argues that cultural production was crucial to this task.

Such cultural work asserted the claims of American citizenship and simultaneously questioned the American national project. It defined, re-interpreted, and refused definitions of blackness itself. Martin's first chapter tells a brief history of the postwar black freedom movement and its precursors in black Left 
organizing. He seeks to examine the "striking paradox" of the American-ness of African Americans who have "historically seen themselves as both essential to and separate from the American nation" (11). And he uses Huggins own formulation of this dilemma and the impact of black cultural production on defining American culture: "what is most remarkable about much that is called black culture is its Americanness; and conversely much of what is considered most uniquely American is essentially Afro American." In the book's most important chapter "Be Real Black for Me," Martin demonstrates the essential role of culture in creating and moulding, exploding and re-imagining ideas of blackness and black people. Beginning with sports—notably Dr. J, Kareem Abdul-Jabbar, and the 1968 Olympic protest, the chapter surveys dance, art, and photography to show how these artists made visible a Black self in places and spaces where Blackness had been obscured or excluded. Martin looks at the work of more well-known artists like Romare Bearden and Gordon Parks but insists that lesser-known artists like Elizabeth Catlett and Betye Saar in their "dogged insistence on blackness and feminism, not to mention Americanness...constitute an even more challenging critique of the American art world and American culture" (108). Thus, in an important contribution, Martin challenges what has been the tacit masculinization of 1960s black cultural politics_-focusing as it has on cultural workers such as Amiri Baraka, Ron Karenga, and Muhammad Ali. And in doing so, Martin demonstrates how definitions of art and self, of manhood, womanhood and nationhood itself were transformed in the process.

Unfortunately, the narrative Martin lays out of the movement's trajectory is somewhat conventional-Martin seems to have missed many of the works published in the past ten years that question the 1950s as a period of de-radicalization, that de-centre the South in favour of a movement that sprang up across the nation, that break down the periodization and ideological boundaries between Civil Rights and Black Power, and that have brought a whole new set of characters to the story beyond the NAACP, Fannie Lou Hamer, and the Black Panther Party. His analysis of the alienating embrace and seductive repulsion of America is a powerful one and could have been strengthened even further with a more complex view of the movement and its players.

While Martin's book takes broad strokes (given the methodological constraints of a set of lectures), Nikhil Pal Singh's Black Is a Country: Race and the Unfinished Struggle for Democracy fills in a crucial set of details on the question of Americanism - on how African American radicals conceptualized the nation and, inspired by global happenings such as the Bandung Conference, imagined a struggle against American racialism at home and abroad. Singh opens with Martin Luther King's criticisms of Vietnam and his rapid vilification to mark the "disjunction between as a redemptive national icon and King as an unsettling figure in opposition to the nation state" (4). He reminds us that the 1930s, 1940s, and 1950 s — and particularly the context of the Cold War-were a crucial period of 
formation and contestation for the movement. Singh begins in the 1930s to chart a 'long' civil rights movement with W.E.B. Du Bois' prescient critique of white nationalism at the heart of the New Deal liberalism. In starting with the New Deal, Singh reveals a crucial dimension of American racism—that obscured from view in the mid-twentieth century a new social citizenship was institutionalized that entrenched black people as second class citizens-and shows the ways that a series of African American thinkers from Du Bois to Paul Robeson to Malcolm X would seek to reveal these modern (and liberal) roots of American apartheid.

In one of the book's strongest chapters "Americanizing the Negro," Singh offers a potent criticism of Gunnar Myrdal's An American Dilemma and liberal social science more generally. He delineates the ways Myrdal's study foregrounded the question of racism as America's tragic flaw; this recapitulation of American exceptionalism-even as Myrdal lambasted America's racial caste system-thus delimited the power of Myrdal's intervention and much of the liberal social science that looked at race during this period. Black people would still be constructed as a culture to be studied and thus chambered outside the bounds of the nation. An American Dilemma powerfully indicted the damage racism did to the strength of the United States but "preserved...the oppressive interrogative long at the center of U.S. discourse on race: 'How does it feel to be a problem?"' (151).

While documenting the ways Cold War ideology provided a justification for attempts to silence many of these voices, Singh writes against a declension narrative of the 1950s as a nadir of progressive activism. But he does not provide much of a window onto the 'less well known participants,' implicitly rendering the driving vision of black radicalism as the purview of a series of charismatic leaders and missing a number of characters and movements that persist through the 1950s despite the hostile climate.

Part intellectual history, Singh offers a powerful argument on the nature of American political thought in the twentieth century-and the ways that these thinkers (often not included in the American canon precisely because of their opposition to US policy) challenged the terms of American nationalism. Rejecting the rationality of American democracy, men like Paul Robeson and Malcolm X saw Whiteness as the organizing force of American nationalism. They saw it justifying US imperialism abroad, deep racial and economic inequality at home, and a strategic embrace of a narrow swath of the civil rights movement (while demonizing the rest) to help the US' image in a Cold War global order. Unlike Waldo Martin, however, Singh's cast is overwhelmingly male-Paul Robeson, Martin Luther King, C.L.R. James, Richard Wright, Malcolm X. Female architects of postwar radicalism such as Vicki Garvin, Eslanda Robeson, Mae Mallory, Gloria Richardson, Pauli Murray, and Maya Angelou do not appear in Singh's narrative while Ella Baker and Angela Davis make brief cameos. This is a curious oversight for a book that takes black radical thought as its heart. It speaks to a troubling new tendency in revisionist histories of the movement to treat women as the 
workhorses of the movement, to be willing to see women as the movement's backbone but not also its brains.

Martha Biondi, like Nikhil Singh, has written a scathing critique of the politics of anti-Communism — not just its often-paranoid fantasies and rights violations. Biondi powerfully argues that the damaging legacy of anti-Communism lies in the ways it crippled a vision for a more just and equal New York City, and, by extension, the nation by destroying the careers of many of its most visionary citizens. Biondi's To Stand and Fight: The Struggle for Civil Rights in Postwar New York joins an emerging body of scholarship that overturns the Southern focus of Civil Rights history. ${ }^{4} \quad$ Biondi takes us to New York-the home of the largest black community in the nation and, like its more notorious Southern counterparts, segregated in housing, schools, and most public and private accommodations. Biondi powerfully unravels hard and fast distinctions between Northern and Southern racism. Through an examination of numerous incidences of police brutality against African Americans in postwar NYC, the chapter on Northern lynching is a stark reminder of the state-sanctioned violence that ensured Northern segregation and inequality.

Biondi dismantles the prevalent conception of Northern segregation as de facto and thus not upheld and maintained by law by making clear the variety of state actors committed and invested in keeping New York's housing and schools segregated. Her chapter on the construction of the massive-and all-whiteStuyvesant Town on the eastside of Manhattan in the late 1940s powerfully shows the city and state's investment in the construction of this segregated veteran's housing development, the largest in the nation. Met Life received from the city and state "a twenty-five year tax exemption estimated at $\$ 53$, the ceding of public streets, and the condemnation of private property, including the forced removal of ten thousand residents" (122). An interracial movement led by various citizens groups and New York's Communist Party developed to protest, yet the courts upheld segregation at Stuyvesant Town. Biondi explains, "By denying the crucial role of the state, the decision helped to crete the fiction that de facto housing segregation in the North originated outside the law and reflected market forces rather than purposeful, racially exclusionary acts of public policy" (129). Along with detailing the Stuyvesant Town movement, she disrupts conventional periodizations of the movement which frame Montgomery as the first direct action battleground of the movement by showing confrontational campaigns to maintain and open up jobs for blacks in the immediate aftermath of World War II.

To Stand and Fight focuses on the Black Popular Front-indeed, Biondi centers her story on the Black left and their 'alternate vision' of an inclusive and just New York. She rejects the inevitability of a segregated and economically bifurcated New York. Instead she powerfully demonstrates the ways that black activists and their white allies emerged from World War II offering a vision and set of practices to create a multiracial democratic metropolis. At the same time, a col- 
lection of local citizens, liberal politicians and school officials, realtors, and other business interests were willing to compromise this promise of a multiracial city and, aided by the red-baiting of many of these Popular Front activists, were largely successful in doing so. But Biondi reminds us these were choices that people made (and thus could make differently) not the powerful anonymous forces of shifting capitalism. In focusing on the left, however, Biondi under tells the story of local organizing. Particularly around schools, Biondi largely overlooks the emerging school desegregation movement of Reverend Milton Galamison, Ella Baker's leadership of the New York City NAACP, the Harlem Nine, and other local parent actions, Kenneth and Mamie Clark's work and their founding of the Northside Center, and a host of other local mobilizations. Making these local activists a more vivid part of the story would only have strengthened her argument that many New Yorkers envisioned a just and multiracial city and, though thwarted and often discredited, worked to make this promise a reality.

Kenneth Andrews Freedom Is a Constant Struggle: The Mississippi Civil Rights Movement and its Legacy is perhaps the odd man out of these four books methodologically. A social movement analysis of the movement in Mississippi, Andrews marries oral history and archival research with quantitative analysis seeking to examine "movement infrastructure" (which he defines as the combination of leaders, indigenous resources, and local organizations) and the political change that results from it. Dense and sociological in its approach, the book seeks to examine the question of how the Mississippi movement(s) brought about social change. As such, by focusing on organizing, it decisively repudiates a charismatic or legislative approach to the movement's success.

Perhaps the greatest historiographic contribution of Freedom is a Constant Struggle is the way it overturns conventional periodization of the Southern movement. Andrews is as much concerned with grassroots political activity and change after 1965 as during the storied days of the early 1960s. The Civil Rights Act and Voting Rights Act—achieved in part through the activism of the people he describes - do not constitute the climax of the book around which all organizing is measured. Indeed, Freedom is a Constant Struggle reminds us that these acts did not overturn Jim Crow America; the willingness of people to push to have this legislation implemented and enforced did.

The book's sixth chapter examines the ways that local movements sought to gain resources and shape and contest the direction of War on Poverty programs. It shows the ways that the Child Development Group of Mississippi (CDGM) worked through existing movement structures to bring Head Start to the Mississippi counties where there were local movements to support these efforts. The book's seventh chapter looks at the issue of school desegregation post-1965; the rise of new white resistance tactics with freedom of choice plans and the creation of private academies required local activists to develop new ways to challenge them. Andrews examines the development and outcomes of the court case 
Alexander $v$. Holmes where, in 1969, the Supreme Court put an end to freedom of choice plans (which allowed to parents to 'choose' the school their children would attend as a way to get around the desegregation provisions of the 1964 Civil Rights Act) and enforced immediate desegregation in thirty Mississippi counties. While the organizing in Mississippi that led to the Mississippi Freedom Democratic Party's challenge in Atlantic City and the floor of the House has been elegantly documented in John Dittmer's Local People and Charles Payne's I've Got the Light of Freedom, Andrews spends equal attention to the organizing and movement gains of the post 1960s period and persuasively demonstrates that the fruits of the struggle were gained in these later 1960s. Unfortunately, unlike Payne and Dittmer, Andrews believes that movement organizing can be explained outside of telling local people's stories, and his narrative, despite its focus on organizing, is curiously divorced from a detailed rendering of the people behind the actions he describes.

By challenging the popular history of the movement, then, these four books together give us a different view of American democracy — of the ways that race forms a constitutive element in American citizenship and nationhood and the cordoning off in public life and history of those citizens willing to point this out. By returning this critique of American rights and opportunity to the heart of the black freedom struggle, they show the whitewashing of the civil rights movement in many popular renderings of the movement today. Historian Jacquelyn Dowd Hall has written about the political investment in this popular narrative. "Germinated in well-funded right-wing think tanks and broadcast to the general public, this racial narrative had wide appeal, in part because it conformed to white, middle-class interests and flattered national vanities and in part because it resonated with ideals of individual effort and merit that are widely shared." ${ }^{5}$

Part of the importance of these four books-but the difficulty of their message penetrating - is that they do not flatter national vanities. They do not tell a teleological story of American progress though they do demonstrate the courage of a number of Americans to imagine and work to create a new social order. They do not show segregation and racial injustice as a mistake that was corrected in the past but challenge us to reinvent and reorient ourselves to this task in the present.

\section{Notes}

1. As historian Renee Romano elaborates in her analysis of the recent trials of 1960s church bombers, "[T] he trials themselves have become a crucial part of a national narrative of redemption and atonement, proof of the immense changes that have taken place in the racial politics in the United States since the 1960s." Renee Romano and Leigh Raiford, The Civil Rights Movement in American Memory (Athens, Ga.: University of Georgia Press, 2006), 99-100.

2. I am dating this new scholarship with the publication of two crucial studies on the movement in Mississippi: John Dittmer, Local People: The Struggle for Civil Rights in Mississippi (Urbana: University of Illinois Press, 1994) and Charles Payne, I've Got the Light 
of Freedom (Berkeley: University of California Press, 1995). See, also, Joanne Grant, Ella Baker: Freedom Bound (New York: John Wiley \& Sons, 1999); Chana Kai Lee, For Freedom's Sake: The Life of Fannie Lou Hamer (Chicago: University of Illinois Press, 2000); Cynthia Fleming, Soon We Will Not Cry: The Liberation of Ruby Doris Smith Robinson (New York: Rowman and Littlefield, 1998); eds. Bettye Collier Thomas and V.P. Franklin, Sisters in the Struggle (New York: New York University Press, 2001); Belinda Robnett, How Long, How Long: African American Women and the Struggle for Freedom and Justice (New York; Oxford University Press, 1997); John D'Emilio, Lost Prophet: The Life and Times of Bayard Rustin (New York: Free Press, 2003); Joy James, Shadowboxing: Representations of Black Feminist Politics (New York: St. Martin's Press, 1999); Barbara Ransby, Ella Baker and the Blacke Freedom Movement: A Radical Democratic Vision (Chapel Hill: University of North Carolina Press, 2003); Tim Tyson, Radio Free Dixie (Chapel Hill: University of North Carolina Press, 1999); Peter Levy Civil War on Race Street: The Civil Rights Movement in Cambridge, Maryland (Gainesville: University Press, of Florida, 2003); Charles Jones ed., The Black Panther Party Reconsidered (Baltimore: Black World Press, 1998); eds. Kathleen Cleaver and George Katsiaficas, Liberation, Imagination and the Black Panther Party: A New Look at the Panthers and their Legacy (New York: Routledge, 2001); Wendell Pritchett Brownsville, Brooklyn (Chicago: University of Chicago Press, 2002).

3. See Robin Kelley, Freedom Dreams; The Black Radical Imagination (Boston: Beacon, 2002). 4. See Jeanne Theoharis and Komozi Woodard, Freedom North: The Black Freedom Struggle Ousdie of the South, 1940-1980 (New York: Palgrave Macmillan, 2002) and Groundwork: Local Black Freedom Movements in America (New York: New York University Press, 2003). On the Northeast, see Clarence Taylor, Knocking at Our Own Door: Milton A. Galamison and the Struggle to Integrate New York City Schools (New York: Columbia University Press, 1997); Wendell Pritchett Brownsville, Brooklyn (Chicago: University of Chicago Press, 2002); Matthew Countryman Up South (Philadelphia: University of Pennsylvania Press, 2005). On the West, see Josh Sides, L.A. City Limits: African American Los Angeles from the Great Depression to the Present (Berkeley: University of California Press, 2003); Becky Nicolaides, My Blue Heaven: Life and Politics in the Working-Class Suburbs of Los Angeles, 1920-1965. (Chicago: University of Chicago Press, 2001); Quintard Taylor, In Search of the Racial Frontier (New York: W.W. Norton, 1998); eds. Lawrence de Graafe et al., Seeking El Dorado: African Americans in California (Los Angeles: Autry Museum of Western Heritage, 2001); Douglas Flamming, Bound for Freedom: Black Los Angeles in Jim Crow America (Berkeley: University of California Press, 2005); Regina Freer, "L.A. Race Woman": 607-632; Josh Sides, "Straight into Compton: American Dreams, Urban Nightmares, and the Metamorphosis of a Black Suburb" American Quarterly 56, vol. 3 (2004): 583-605. Also Robert Self's work on Oakland, American Babylon: Race and the Struggle for Postwar Oakland (Princeton: Princeton University Press, 2003).

5. Jacquelyn Dowd Hall, "Civil Rights and the Political Uses of the Past" Journal of American History 91, vol. 4 (March 2005): 1233-1263. 